\title{
Measuring Levels of Work in Academic Libraries: A Time Based Approach
}

\author{
Donald P. Gould
}

Librarianship has failed to resolve the issue of the differentiation between professional and nonprofessional work or to analyze what constitutes each level of work. Using Stratified Systems Theory, which focuses on the relationship between manager and subordinate in the bureaucratic structure, a study was conducted to measure the level of responsibility in the work of thirty-seven professional and nonprofessional positions in four academic library technical services departments. Three levels of work were measured in "time-spans of discretion" of between two weeks and eighteen months, corresponding to work strata 1 through 3 . Results also showed an overlap in levels of responsibility between professional and nonprofessional positions at the Stratum 2 level. In addition, a high correlation was found between level of work measured and what the subordinate felt was a fair rate of pay for the work performed.

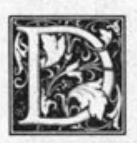

uring much of its modern history, the library profession has been concerned with questions about what differentiates the various levels of work in libraries, and to what extent librarians can consider themselves professionals. These issues, and the attempt to analyze what constitutes each level of work, have been addressed from several perspectives over the years, with no clear resolution. As far back as 1922, Elizabeth M. Coulter, a reference librarian at the University of California, wrote that proper recognition would come to librarians if, among other things, professional and clerical duties were differentiated. ${ }^{1}$

Mary Lee Bundy and Paul Wasserman summed up the problem of utilization of professionals and nonprofessionals by noting the failure of libraries to analyze systematically their personnel structures and requirements. As a result, many librarians are employed in work that does not "call for their full range of preparation. ${ }^{\prime 2}$ Lester Asheim called for a thor- ough revision of job descriptions and job classification schemes "by some new approach in an effort to more fully utilize the particular talents and qualifications of every staff member.",3

More than a decade and a half have passed since Asheim's statement, but little real progress has been made in analyzing personnel structures. The changes that have taken place have resulted more from the impact of technology and funding cuts than from serious research into the nature of work roles in libraries. The challenge to improve the management and effectiveness of libraries is no less urgent today. Indeed, issues such as comparable worth, collective bargaining, and erosion of financial support make it imperative that library managers seek new solutions.

This article reports the results of a doctoral dissertation. It is the first such study of levels of work in libraries and the first study known to use this particular theoretical approach on a cross-institutional basis. As such, it is necessarily oriented to 
methodological concerns as well as the attempt to examine the issue of levels of work in libraries. The intent is to make a contribution to the research base of librarianship and provide an academic research agenda. Just as important is the hope that the results of this, and subsequent studies, will lead to improvements in the practice of librarianship and the management of libraries.

\section{DIFFERENTIATING LEVELS OF LIBRARY WORK}

Charles C. Williamson's landmark report in 1923, Training for Library Service, used the terms "professional". and "clerical," but pointed out that "the distinction between the two is only vaguely understood and seldom applied in library organization and practice." He went on to castigate library administrators for not clarifying the qualifications needed for different types of work. ${ }^{4}$ Two years later George A. Works noted the insufficient distinction made in libraries between clerical and professional types of service. ${ }^{5}$ More recently Asheim ${ }^{6}$ and Dale E. Shaf$\mathrm{fer}^{7}$ recommended better ways to distinguish between the professional and nonprofessional tasks performed in libraries. Olga B. Bishop further documented the failure to separate professional from nonprofessional duties. ${ }^{8}$

Much of the effort in differentiating professional from nonprofessional work has concentrated on developing position classification and pay plans for compensation purposes and lists of appropriate duties. Beginning with the lists published by the American Library Association in $1927^{\circ}$ and $1929^{10}$ and the California Library Association in $1932,{ }^{11}$ a succession of plans and lists were issued, culminating in the 1970 Library Education and Manpower statement, which recommended "categories of library personnel, and levels of training and education appropriate to the preparation of personnel for these categories." ${ }^{12}$ The document was revised in 1976, and the resulting Library Education and Personnel Utilization statement is currently considered official policy by ALA.

The ALA statement recognizes three levels of nonprofessional personnel- clerks (high school education), assistants (two years of college), and associates (bachelor's degree)-in addition to the professional positions requiring the master's degree. The statement avoids listing duties appropriate to each level, concentrating instead on a descriptive approach by providing a brief analysis of the "nature of responsibilities" required for the positions.

\section{WORK ANALYSIS IN LIBRARIES}

The analysis of work in libraries has concentrated on the activities performed, using standard task analysis techniques. This traditional job evaluation approach attempts to provide a means for deriving indexes of relative job values within an organization by various rating schemes. Examples include such studies as the Illinois Library Task Analysis Project, ${ }^{14}$ Charlotte Mugnier's study of paraprofessionals in public libraries, ${ }^{15}$ and the health sciences library personnel study by Leslie-Beth Rothenburg and others. ${ }^{16}$

Traditional task analysis and job evaluation schemes have several serious drawbacks. For example, the assessments are made by persons, both inside and outside the organization, who are not held accountable for the work of the person or position being analyzed. As will be examined below, the way that work is delegated-the realities of specific accountability and authority-is what sets the level of responsibility in work, ${ }^{17}$ not the activity in and of itself. It is the goal of the activity, the output or result, as judged by the person who is to be held accountable for the work being performed that sets the level of work. The studies cited above have been useful for compiling lists of activities but have yielded little in the way of results that are generalizable, or not institution-specific, and have contributed little to a fundamental understanding of the meaning of levels of responsibility in work. In this paper, the terms level of work and level of responsibility are interchangeable and refer to the relative position within an organization, with higherlevel work being deemed "more responsible." 


\section{THE ISSUE OF PAY} IN LIBRARY WORK

Although the earlier attempts to differentiate professional from nonprofessional work revolved around position classification and pay plans, there has been a curious lack of research into the issue of pay itself. Those studies that have been done, such as Richard B. Eggleton's in 1978, have focused on pay as one element in the job satisfaction equation ${ }^{18}$ and shown it to be a chief source of dissatisfaction among librarians.

It is not surprising that librarianship has avoided such studies when considering the general paucity of substantive social science research on the question of pay. ${ }^{19}$ Despite the overwhelming importance of pay as the primary system for reward and compensation in work, ${ }^{20}$ modern organizational theorists have tended to view the pay question within the context of generalized psychological theories of motivation or satisfaction. ${ }^{21}$

\section{LIBRARIES AS BUREAUCRACIES}

Libraries belong to that class of social organization known as bureaucracies, a type of employment system in which people are hired to produce an output, a result, in return for a wage or salary. About 90 percent of the work force in industrialized countries is employed in bureaucracies ranging from government agencies to schools, factories, small and large businesses, hospitals, etc. Furthermore, these social institutions are organized hierarchically, in which persons within the organization are ranked one above the other. This hierarchy of levels has generally been taken for granted. It is understood that the people at the top of the organization receive significantly higher levels of responsibility, earnings, and status than people at the lower levels. ${ }^{22}$

It might be questioned whether libraries can be considered typical bureaucracies in view of the fact that they employ large numbers of "professionals," but many hierarchically structured organizations employ professionals: hospitals, schools, social service agencies, and even businesses with research divisions. It cannot be successfully argued that libraries are exempt from consideration as bureaucracies simply because of their "unique" staffing patterns. If these staffing patterns are unique, then the role relationships therein need to be studied as they relate to the goals of the bureaucratic organization within which they exist. In fact, several library thinkers have examined this conflict between professional and bureaucratic authority, concluding that the professional function is weak to the point of ineffectiveness. ${ }^{23,24}$

The structure and nature of work in bureaucratic organizations are the direct concern of the theoretical approach developed over the past forty years by Elliott Jaques at Brunel University in Great Britain. Jaques' theory, known as "stratified systems theory," seeks to understand the nature of work and human capability for work within the context of hierarchically structured organizations commonly called bureaucracies. For Jaques, bureaucracies, or what he also refers to as employment hierarchies, are a natural social phenomenon that arose out of society's need to employ people to get work done.

Stratification and managerial control are vital aspects of bureaucratic functioning, and it is the manager-subordinate relationship that constitutes the basic social structure of bureaucratic systems. All work is managerially assigned or sanctioned and contains both prescribed limits of expense, quality and time, to which the subordinate must adhere, and a discretionary aspect. ${ }^{25}$

Jaques' definition of work is vital to an understanding of his theoretical approach: It is the exercise of discretion within prescribed limits of expense, quality, and time. The limits are established, either explicitly or implicitly, by the employing authority (board of directors, trustees, voters, etc.) and are delegated downward through the managerial structure. ${ }^{26}$ The exercise of discretion means acting in a climate of uncertainty, making judgments, deciding on alternative means for accomplishing the job. It requires the person to tolerate uncertainty and anxiety about the results of the work. It is the discretionary aspect of work that requires a balance between analysis and intuition in the "continuing process of sensing a po- 
tential problem, defining it and constructing a solution. ${ }^{\prime 27}$ The longer the period of time that a person must stand up to uncertainty and anxiety, the greater the psychological feeling of the weight of responsibility, and thus the greater the level of work.

For Jaques, all work is goal-oriented. Furthermore, the achievement of the goal must have a realistic, objective time limit, a "target completion time." ${ }^{28}$ As the period of time between the initiation of a task and its expected completion increases, the path to completion gets longer and more complex and the number of obstacles and amount of information to be gathered and processed increases, as do the number of tasks to be organized and handled.

This discovery led Jaques to develop a measure for determining the level of responsibility in any work role, which he called the "time-span of discretion." Since all work is managerially assigned or sanctioned, the time-span of any role may therefore be objectively measured by getting the manager to determine the longest forward target completion time for any single task assigned to a subordinate. It is the manager, the person who will be held accountable for the work of a subordinate, who determines the time-span, and thus the level of responsibility in any work role. It is the single longest period of time for any single task that sets the level of work.

The essence of the time-span of discretion measure is to examine the task content of the work and arrive at accurate, reliable work measures that can be objectively understood by a third party and are both generalizable and not institution-specific. The level of responsibility in a role is not dependent upon the number of subordinates, length of training, education, or skill, or any of the myriad factors upon which traditional job evaluation techniques usually rely. Thus, for example, the measure for determining level of responsibility in professional work is the same as for managerial work and provides a basis for comparison of these seemingly different roles. Other factors are also valid concerns, but for purposes of establishing level of work it is the timespan of discretion that is the single, measureable factor.
Much of the early criticism of Jaques' theory revolved around his failure to provide sufficient empirical evidence to support his claims. ${ }^{29}$ Hard data continues to be a problem because of the proprietary nature of many of the studies conducted for businesses and government agencies. Paul Goodman challenged Jaques' concept of time-span, but he failed to understand the very concept by seeking to "measure" time-span with a single-item questionnaire. $^{30}$

\section{MANAGER-SUBORDINATE RELATIONSHIP}

Jaques believes that the first problem of bureaucratic organizations has been the failure to describe and specify adequately the main role relationships. He sees the key relationship, the one on which the bureaucratic hierarchy is built, as the manager-subordinate relationship. Managers must be held accountable not only for their own work, but the work of their subordinates, else the work will not get done. Problems arise when managers are not given the authority required to carry out their duties. ${ }^{31}$ To do this, the manager must have at least minimal authority to veto new appointments, decide performance appraisals, and deselect unsuitable subordinates. Jaques' definition is remarkably simple and effective in explaining the complex social relationship between manager and subordinate and is the first to provide a clear and concise definition of managerial work.

Jaques' theory also examines horizontal role relationships and those of nonmanagerial positions such as professionals and technical specialists. The need to understand and clarify these relationships in terms of the functioning of the bureaucracy is no less critical. In fact, the failure to understand the different organizational role requirements for managers, technical specialists, and professionals has exacerbated the problems faced by many organizations, including libraries.

\section{STRATIFICATION IN BUREAUCRACIES}

Stratified systems theory proposes that human work-capacity, the ability to engage in goal-directed behavior in work 
roles, is a function of the length of the period that a person is capable of managing activity through time. Furthermore, the very nature of work-capacity, unlike intelligence as measured by IQ tests, is viewed as discontinuous; ${ }^{33}$ that is, there are changes in the way people at different time-span levels actually work. These differences occur in their perception of tasks, the planning and organization of their work, their accumulation of experiences, and "in the fullest sense, qualitative differences in the way they picture the world in which they are working. ${ }^{\prime 34}$ The content of any work activity is distinctly different from the purpose or goal of that activity, and it cannot be assumed that any two people with the same job title are doing the same level of work. ${ }^{35}$

The results of applying the time-span of discretion measure led to the discovery of stratification in bureaucratic organizations. It revealed a pattern of discontinuous levels of work. These levels fall at regular intervals of three months, one year, two years, five years, ten years, and twenty years. Evidence points to the existence of even higher levels of fifty and one hundred years (see table 1). These levels of stratification, corresponding to levels of work and responsibility, suggest the existence of an optimal structure of working levels within bureaucratic hierarchies.

As stated above, the way in which two people perceive the same problem or activity will vary according to differences in their ability to draw abstractions over time. These individual differences in levels of abstraction (levels of work-capacity) are also observable in the depth-structure of bureaucratic hierarchies. Work requirements at each of the levels-that is, what is required to accomplish the goals of the job-are similarly discontinuous. Ralph Rowbottom and David Billis found that successively higher strata are judged to be more responsible and that there are significant differences of responsibility even within strata, forming a continuous scale of increasing levels of work. ${ }^{36}$ Ideally, a person's capability at a point in time will match the work level of his or her current job. The work strata are described below, and complete descriptions are provided in
Rowbottom and Billis' The Stratification of Work and Organizational Design and Jaques' Free Enterprise, Fair Employment. ${ }^{37}$

- Stratum 1-Prescribed Output (timespan of one day to three months): The output required is very concrete, completely prescribed, or able to be prescribed, as are the specific circumstances in which the tasks should be pursued. The work is anchored in rules. No decisions are made by the worker about what is to be done, only on how to go about it, by what method, and with what priority.

- Stratum 2-Situational Response (timespan of three to twelve months): Objectives must be judged according to the needs of each specific, concrete situation that arises. The work at this level, rather than solely producing a specific output or providing a prescribed service, consists of producing an appraisal or making an assessment. There is greater complexity than at Stratum 1, requiring the ability to handle a number of problems at one time and to work on them intermittently. This is the first-line managerial, professional, and technical level.

- Stratum 3-Systematic Service Provision (time-span of one to two years); The work goes beyond specific, concrete, case-by-case situations, to a need for envisioning a continuing sequence of situations. It involves problem solving and the development of systems and procedures that prescribe the way work in Strata 1 and 2 is to be carried out. Ambiguity is increased over that in Stratum 2.

- Stratum 4-Comprehensive Service Provision (time-span of two to five years): Work at this level requires the application of intuitive judgment to detect gaps in services, the ability to maintain mental contact with what exists but to detach from the day-to-day situation and develop new ideas that are a departure from the old. Problems are no longer seen in terms of individual tasks. There is a substantial increase in uncertainty compared with Stratum 3.

- Stratum 5-Comprehensive Field Coverage (time-span of five to ten years): 
This is the level of the managing director. Stamp refers to this level as "redefinition of the rule. ${ }^{\prime \prime 3}$ It is characterized by entrepreneurial development and the development of new scientific or technical knowledge. The work domain at this level has become universalized, requiring the individual to operate in a mode unconstrained by existing words, ideas, or theories and to seek reformulations and original solutions.

Strata 6 and 7 have time-spans of ten to twenty years and twenty to fifty or more years, respectively, and are found only in the largest and most complex organizations. The levels of abstraction are such that the concern is with whole social and theoretical systems on a worldwide scale.

The descriptions of work strata and the levels of abstraction required at each stratum are extremely useful for clarifying roles and role relationships, for analyzing organizational structure in existing organizations, and for aiding in the design of new organizations. Table 1 illustrates the relationship between time-span, levels of abstraction, and work strata and the actual organizational structure found to exist in both the public and private sectors. It also illustrates how professionals and technical specialists fit into the hierarchical structure.

The research points to this depth structure as universal, providing a formula for designing bureaucratic organizations. By measuring the time-span at the top level of the bureaucratic structure, it is possible to determine the optimum number of managerial levels in the organization. The optimum distance between managerial levels is always one stratum. Real managerial and professional work emerges in Stratum 2, although trainees and interns are often found in Stratum 1. The results of poor managerial decisions in setting levels of work do not go unnoticed. The organizational consequences for improperly setting levels of work are profound.

Having too many levels results in commonly experienced dysfunctions: excessively long lines of command that result in much bypassing; uncertainty about who one's manager really is; too much red tape; or a feeling of too many levels being involved in a problem, or of the manager "breathing down one's neck." The result of having more than a one-stratum distance between the manager and subordinate is a subordinate's feeling of too great a distance from the manager. The manager, on the other hand, becomes impatient, expecting too much too quickly and a feeling that he or she must get involved in too much detail.

\section{"FELT-FAIR" PAY}

During his work Jaques accidentally discovered a high correlation between time-

TABLE 1

TIME-SPAN, WORK STRATA, AND DEPTH STRUCTURE IN ORGANIZATIONS

\begin{tabular}{|c|c|c|c|c|c|}
\hline $\begin{array}{l}\text { Time- } \\
\text { Span }\end{array}$ & $\begin{array}{c}\text { Work } \\
\text { Stratum }\end{array}$ & Business & Military & $\begin{array}{l}\text { U.S. Civil } \\
\text { Service }\end{array}$ & $\begin{array}{l}\text { Professional/ } \\
\text { Technical }\end{array}$ \\
\hline $20-50$ Yrs. & VII & Corporation & $\begin{array}{l}\text { Army } \\
\text { (General) }\end{array}$ & Exec 1-2 & - \\
\hline $10-20$ Yrs. & VI & $\begin{array}{l}\text { Corporate } \\
\text { Group of } \\
\text { Subsidiaries }\end{array}$ & Corps & Exec 3-5 & - \\
\hline 5-10 Yrs. & V & $\begin{array}{l}\text { Corporate } \\
\text { Subsidiary }\end{array}$ & $\begin{array}{l}\text { Division } \\
\text { (Maj. Gen.) }\end{array}$ & GS $17-18$ & $\begin{array}{l}\text { Senior } \\
\text { Specialist }\end{array}$ \\
\hline 2-5 Yrs. & IV & $\begin{array}{l}\text { General } \\
\text { Management }\end{array}$ & $\begin{array}{l}\text { Brigade } \\
\text { (Brig. Gen.) }\end{array}$ & GS $14-16$ & $\begin{array}{l}\text { Chief } \\
\text { Specialist }\end{array}$ \\
\hline 1-2 Yrs. & III & $\begin{array}{l}\text { Departmental } \\
\text { Management }\end{array}$ & $\begin{array}{l}\text { Battalion } \\
\text { (Lt. Col.) }\end{array}$ & GS $10-13$ & $\begin{array}{l}\text { Principal } \\
\text { Specialist }\end{array}$ \\
\hline 3 Mos. -1 Yr. & II & $\begin{array}{l}\text { First-Line } \\
\text { Management }\end{array}$ & $\begin{array}{l}\text { Company } \\
\text { (Captain) }\end{array}$ & GS 6-9 & Specialist \\
\hline 1 Day-3 Mos. & I & $\begin{array}{l}\text { Shop \& } \\
\text { Office Floor }\end{array}$ & $\begin{array}{l}\text { Platoons } \\
\text { Squads } \\
\text { (NCOs) }\end{array}$ & GS $1-5$ & - \\
\hline 1 Day & - & - & - & - & - \\
\hline
\end{tabular}


span and what employees' sense is a fair rate of pay for the work they are performing. Employees working at the same level, as measured by their time-span of discretion and independent of other factors such as type of work, age, sex, education, etc., state similar "felt-fair" pay rates. ${ }^{39}$ In much of Jaques' work, including research done with Wilfred Brown, ${ }^{40}$ and in studies by Roy Richardson, ${ }^{41}$ G. E. Krimpas, ${ }^{42}$ and Donald P. Gould, ${ }^{43}$ it was found that for each time-span level there was a corresponding level of pay that employees felt to be fair, a concept that has come to be called "felt-fair" pay. The correlations have been reported at approximately +.90 .

The results of chronic disparity between actual and equitable payment levels for socially connected groups, such as a professional group or members of the same organization, are cumulative and include low morale, chronic complaints about physical conditions or lack of opportunity, high turnover, and loss of qualified persons. Conversely, payment above equity results in feelings of anxiety, guilt, resistance to change and introduction of new work methods, and development of intransigent attitudes. ${ }^{44}$

The implications of Jaques' fair-pay findings are extremely significant. The fact that fair pay correlates so highly with time-span could lead to a linear ranking of all occupations from lowest to highest and the establishment of a shared sense of fairness regarding pay. An equitable workpayment scale opens up enormous possibilities ranging from the common situations of managers recommending pay increases for subordinates to issues of national importance, such as equal pay for comparable work.

\section{THE STUDY}

This study applied Jaques' theory to the work in academic library technical services departments in order to determine levels of work performed and to differentiate professional from nonprofessional work. It was hypothesized that distinct levels of work, corresponding to the first three time-span strata, would be found in the libraries studied. These positions have traditionally been identified as nonprofessional and professional, with an intermediate paraprofessional level that has never gained widespread formal acceptance. It was further hypothesized that persons at the same levels of work, as measured by time-span of discretion, would express the same rates of fair pay regardless of their actual work assignments or institutional job designations.

An approximately equal number of professional and nonprofessional employees were selected in four academic libraries ranging in size from roughly five hundred thousand to one million volumes. The libraries were selected on the basis of size, availability to the researcher, and their managements' willingness to participate. Precise matching of libraries by size was deemed neither important nor particularly advantageous. If differences in work roles in libraries of somewhat different size and/or structure emerged, so much the better, as it might provide additional directions for future research.

Included in the nonprofessional work roles studied are positions commonly known as library clerks and library assistants, in the following departments: acquisitions, bibliography/collection development, cataloging, circulation, serials, and data processing. Professional positions included the following: acquisitions librarians, catalogers, and collection development librarians. Individuals were randomly selected from lists of professional and nonprofessional employees arranged by job classification. A total of seventeen professionals and twenty nonprofessionals were included.

The methodology for data collection departed somewhat from traditional timespan studies that use an approach known as social analysis. Based on a long-term consultancy relationship, the social analyst offers help to a client group in return for information not ordinarily available in traditional social scientific research methodologies. ${ }^{45}$ Social analysis has a dual role of promoting change while providing a research opportunity. The purpose of this research project was not to introduce change but to examine an occupational field in several institutional 
settings. It was thus necessary to develop a modified methodological approach, which the reader is encouraged to examine more closely before attempting to replicate this study.

Between the two extremes of the survey and participant observation approaches lies a methodology known as "intensive interviewing," an approach that uses a guided conversation and seeks to elicit materials of substantial depth for use in qualitative analysis. ${ }^{46}$ This study used a combination of intensive interviews and structured questions to determine the following information about specific jobs for which Jaques and others have used the social analytic approach:

- the specific tasks in the job as described by the person in the job;

- the identification of whomever the subordinate perceives to be his or her true manager;

- the amount the employee feels to be a fair rate of pay for the work he or she is doing;

- the determination, on the part of the manager, of target completion times for the longest tasks assigned;

- any other data relevant to identifying the level of work for the job;

Interviews were conducted with the selected subordinates in order to identify the tasks in their roles. Participation was strictly voluntary, and interviews were conducted under conditions of confidentiality. At the end of each interview two structured questions were asked. The first sought to identify the person's manager according to Jaques' definition. The second question asked the subordinates to state what they felt would be a fair rate of pay for the work they were doing.

The issue of pay is a sensitive one. Determination of "felt-fair" pay can only be conducted under conditions of strict confidentiality and independence of the researcher from the organization.

Upon completion of the subordinate interviews, managers were interviewed. The manager interview is the key to timespan determination, for although it is possible to get a sense of time constraints from the person in the job, it is the manager who must decide the objective fact of when work is to be completed and to what level of quality. The purpose of this interview was solely and completely to get the manager to come to a firm decision, if possible, about target completion times for the assigned tasks. In most cases it was necessary to conduct several interviews with the managers. Two indispensable guides for determining time-spans are Jaques' Time-Span Handbook ${ }^{47}$ and John S. Evans' critical work, The Management of Human Capacity.

Time-spans did not always emerge as neatly as one would have liked. One aspect of time-span measurement that makes it less than desirable for quick and easy job evaluation is its tendency to quickly reveal weaknesses in the executive structure. ${ }^{48}$ In cases where managerial links are weak, such as among professionals, or where the organizational levels are compressed, the ostensible manager may indeed be operating at the same time-span level as the supposed subordinate, and thus measurement is impossible. Timespan research has shown that employees working at the same level of responsibility are unable to articulate the prescribed limits of others at that work level. Measurement is also difficult or impossible in situations where lines of authority and accountability are weak.

Difficulties may also arise from a misunderstanding of the task concept of work and the reluctance of people to verbalize tasks. Managers simply have not been trained to think in terms of the task content of work or in terms of implicit time constraints.

In addition to time-span data, the interviews began to reveal a consistent pattern of descriptive data about the ways in which people approached their work. In keeping with the qualitative descriptions of abstraction levels within work strata, it was observed that the complexity of the work changed dramatically as the level of responsibility, as measured by time-span, increased. Collection of this descriptive data was not part of the original research design, but began to emerge during the early, pretest, stages of interviewing. During the interviews with both subordinates and managers it became evident that there 
were obvious, qualitative differences in the way in which the work, at different levels, required the person in the job to go about carrying out that work. These observations reflect the demands of the work as assigned by the manager, not the capability of the individuals in the jobs.

Subjects were assigned to the appropriate stratum based on their measured timespan of discretion and/or their level of abstraction in work as determined in the interviews. There were no cases in which the time-span of discretion measure and the level of abstraction data were in serious conflict. However, in several cases time-spans were on the borderline between strata; in these cases the qualitative level of abstraction data was used to determine the appropriate stratum.

\section{RESULTS}

Distinct levels of work were found to exist in academic library technical services departments, as measured by time-span of discretion and corresponding to Strata 1 through 3. All those in Stratum 1 were in nonprofessional positions, while Stratum 3 included only professional positions. However, this study found a definite, observable, measurable overlap between professional and nonprofessional library work at the Stratum 2 level.

Nonprofessional work carried timespans of between two weeks and twelve months, with the majority of positions (70 percent) at Stratum 1. The work conformed to the descriptions of work at Strata 1 and 2 levels. Professional positions emerged at the low end of Stratum 2, up to the middle of Stratum 3, with timespans of between three and eighteen months and corresponding descriptions. The results are summarized in table 2 .

This study also found an extremely high correlation between what respondents perceived to be a fair rate of pay for the work they were doing and the level of responsibility in their work, as measured by their time-span of discretion. The correlation coefficient was $r=+0.95$. Table 3 summarizes these results.

The "felt-fair" pay results are striking and support the findings of other timespan studies done by Richardson, Krimpas, and Jaques and Brown, noted above. Both professional and nonprofessional library employees evidenced a strong sense of what they considered fair pay for the work they were doing. Moreover, their sense of fair pay was consistent with their

TABLE 2

SUMMARY OF TIME-SPAN OF DISCRETION BY STATUS

\begin{tabular}{lccccccr}
\hline \hline $\begin{array}{l}\text { Time-Span } \\
\text { (in months) }\end{array}$ & .5 & 1 & 2 & 3 & 6 & 12 & 18 \\
\hline Status & $1 \mathrm{~N}$ & $4 \mathrm{~N}$ & $7 \mathrm{~N}$ & $2 \mathrm{~N}$ & $4 \mathrm{~N}$ & $2 \mathrm{~N}$ & $9 \mathrm{P}$ \\
\hline
\end{tabular}

$\mathrm{N}=$ nonprofessional, $\mathrm{P}=$ professional.

TABLE 3

SUMMARY OF "FELT-FAIR" PAY (FFP) BY TIME-SPAN OF DISCRETION (TSD)

\begin{tabular}{lccccccc}
\hline \hline $\begin{array}{l}\text { TSD } \\
\text { (in months) }\end{array}$ & Stratum 1 & \multicolumn{3}{c}{ Stratum 2 } & \multicolumn{2}{c}{ Stratum 3 } \\
\hline FFP (in & 1 & 2 & 3 & 6 & 12 & 18 \\
thousands & 15 & 12 & 20 & 18 & 24 & 30 & 35 \\
of dollars) & & 15.5 & 18 & 18 & 21 & 25 & 35 \\
& & 15.5 & 20 & 19 & 25 & 34 & 35 \\
& 15.5 & 20 & {$[19]$} & 23 & 27 & 35 \\
& & & 11 & {$[19]$} & & 27 & 35 \\
& & 18 & {$[21]$} & & & 35 \\
& & 19 & {$[22]$} & & & 30 \\
& & & & & & 35 \\
\hline
\end{tabular}

Note: Figures in brackets are for the four professionals whose time-spans of discretion could not be obtained. 
level of work responsibility as measured by their time-span of discretion, although they worked in separate and distinct institutional settings. Of the four institutions included in the study, three were located in California, two in the same public system and one in a private, independent university. The fourth was a public university located in the Northeast. In the latter case, "felt-fair" pay rates were consistently lower than the other three institutions due to marked regional differences in pay and other economic factors. The fair-pay rates were adjusted, using an average of the difference between three published earnings and income data for the regions.

The four professionals for whom timespans could not be obtained expressed fair-pay rates that place them somewhere between high Stratum 1 and low Stratum 2. Descriptive data indicated that their work conformed to Stratum 2; that is, their work could best be described as situational response work, and in no case were they assigned tasks that met the criteria for Stratum 3 work (systematic service provision).

The results provide further confirmation of Jaques' contention that people share a sense of fairness about the worth, in monetary terms, of the work they are doing. Whether there is a single, societal scale of equitable pay rates, as Jaques proposes, ${ }^{49}$ is a matter requiring further study. This study found that persons employed in academic library technical services departments expressed "felt-fair" pay rates as shown below.

\section{Stratum $1 \$ 15,000$ to $\$ 20,000$ \\ Stratum $2 \$ 20,000$ to $\$ 30,000$ \\ Stratum $3 \$ 30,000$ to $\$ 35,000+$}

In addition to the time-span and fair-pay data, information on the sex and level of education yielded interesting results. The data on education support the requirements established in the ALA personnel utilization statement. ${ }^{50}$ For nonprofessionals in low Stratum 1 with up to a onemonth time-span of discretion, the average education was one and one-half years of college, and all but one had some college background. High Stratum 1 personnel had an average education of about two years of college, with the A.A. degree prevalent. Stratum 2 personnel had an average of more than three years of college; 67 percent had at least a bachelor's degree. Curiously, none of the libraries had personnel classification systems that formally recognized this paraprofessional level. None of the position descriptions required this level of education, although managers agreed that they preferred to hire people who had the bachelor's degree.

This study's results generally support the position descriptions provided in the ALA statement on personnel utilization. In addition to recommending changes in the description of work activities, it was also recommended that an additional professional level be established that would recognize entry-level positions corresponding to Stratum 2 and overlapping the highest nonprofessional level, ${ }^{51}$

Women predominated, as expected, particularly at the lower levels. There was no difference between males and females in "felt-fair" pay when compared to their time-spans of discretion. It would appear that men and women in library work are equally socialized to the fair-pay levels for library work, but this question needs further research.

\section{IMPLICATIONS}

This study provides a beginning to the differentiation of professional and nonprofessional library work through application of the time-span measure. It also offers a means for answering the question of whether librarians are performing work at a level of responsibility equal to professionals and technical specialists in other fields. Most librarians studied were found to be working at Stratum 3 or high Stratum 2, levels at least equal to the beginning levels of other recognized professional and technical fields. That others were found working at low Stratum 2, or expressed corresponding "felt-fair" pay rates, is also significant. This is the level at which real managerial, professional and technical specialist work emerges, yet all of them had been employed in professional positions for some years. The fact that all were employed in the two smaller institutions in the study points to an issue that requires further investigation. To what ex- 
tent was institutional size the prime factor in keeping these levels so low, or were other factors, such as management dysfunctions, responsible?

By applying stratified systems theory, it was possible to distinguish levels of work in the libraries studied. Time-span of discretion did give an objective measure of the manager's subjective determination of the level of work required in a work role. It accomplished this by concentrating on the goal of the activity-the output of the work, rather than the activity itself. This is an important distinction because, as pointed out earlier, past job evaluation studies in libraries have concentrated on the activities of the tasks, with results that were institution-specific and not generalizable.

Time-span analysis also provides a means for comparing work within a single organization, despite differences in actual work activities, and for analyzing the role relationships between various positions. Just as important, it offers a means for comparing and ranking previously noncomparable work roles independently of the organization. The implications for establishing comparable worth and for eliminating biases in determining wages and salaries based on sex or any other irrelevant factors, are significant.

It must be emphasized at this point that the time-span measure applies to specific individual roles studied and not to other roles with the same job title. As Jaques points out, one of the great fallacies in employment systems is the assumption that all jobs with the same title carry the same level of responsibility. What job titles do is describe the kind of activity found in a role. ${ }^{52}$ Considerably more study of library positions will be required before any generalizations can be made about the differentiation of professional and nonprofessional work. Library managers now have available to them not only a tool for performing job evaluations but also a conceptual and theoretical foundation for analyzing the roles and relationships within their institutions. Asheim's call for a new approach to restructuring job descriptions and job classifications may now be answered.
The issue of the library as a bureaucracy and the relationship of professionals to the bureaucratic structure can now be studied within the conceptual framework provided by the time-span approach. Each organization must analyze its own structure and the relationships within, based on the realities of accountability and authority. Libraries have been badly managed in the past, in part at least, precisely for the same reasons found in other bureaucracies: managers have not been given the authority required to carry out their duties, and other role relationships, most notably the managerial/professional relationship, have not been clearly understood.

Stratified systems theory now has been shown to offer a clear opportunity to begin resolving issues that have defied solution for so long: determining levels of work; differentiating professional from nonprofessional work; defining and clarifying the roles of managers, professionals and technical specialists; streamlining the organizational structure; and establishing equitable wage and salary levels.

Time-span analysis also has implications beyond the organization. For example, in education for librarianship and the information services it offers a means for understanding the cognitive, intellectual abilities and skills required at each stratum. By applying the work stratum model educators should be able to assess requirements and design curriculum for the several levels of personnel ranging from clerks to technical specialists, paraprofessionals, professionals, and managers.

The implications of the fair-pay findings for establishing equitable pay rates are profound. If people indeed share a common sense of what is fair pay for the level of work performed, it is then possible to set rates of pay, for all types of work, that reflect these feelings. It is now possible, using this approach, to focus on the issue of pay in library work. Some of the serious personnel problems faced by libraries may indeed be the result of chronic disparity between actual and equitable pay, the effects of which were noted earlier.

The ultimate goal of any organizational study must be the achievement of im- 
proved organizational functioning, contributing to the well-being of not only the organization but also the people in it. This notion is best summed up by Elliott Jaques' concept of the "requisite organization." Such an organization not only meets the objectives that the executive system was set up to attain, but also contributes to the social health of the individuals employed in it by providing for the

major needs of the normal, maturely independent individual . . . his needs to utilize his full capacity in his work; to participate in making the laws to which he and his fellows conform; to have recourse to public processes of appeal; and to receive due recognition and reward. ${ }^{53}$

The single unifying thread through all the discussions in this study of levels of work, responsibility, stratification, executive structure, fair pay, etc., has been the individual and his or her role in the organization. Libraries will achieve success as social institutions meeting the needs of the greater society only to the extent to which they achieve requisiteness for not only the well-being of the executive structure but also for the social health of the individuals who comprise the structure.

\section{REFERENCES}

1. Robert B. Downs, "The Role of the Academic Librarian, 1876-1976," College \& Research Libraries 37:496 (Nov. 1976).

2. Mary Lee Bundy and Paul Wasserman, "Professionalism Reconsidered," College \& Research Libraries 29:17 (Jan. 1968).

3. Lester Asheim, "Manpower: A Call for Action," Library Journal 92:1795 (May 1, 1967).

4. Charles C. Williamson, Training for Library Service: A Report for the Carnegie Corporation of New York (Chicago: American Library Assn., 1923), p.3-4.

5. Downs, "Role of the Academic Librarian," p.496.

6. Asheim, "Manpower."

7. Dale E. Shaffer, The Maturity of Librarianship as a Profession (Metuchen, N.J.: Scarecrow, 1968).

8. Olga B. Bishop, The Use of Professional Staff in Libraries: A Review, 1923-1971 (Ottawa: Canadian Library Assn., 1973).

9. American Library Association, Bureau of Public Personnel Administration, Proposed Classification and Compensation Plans for Library Positions (Chicago: American Library Assn., 1927).

10. American Library Association, Committee on the Classification of Library Personnel, Budgets, Classification and Compensation Plans for University and College Libraries (Chicago: American Library Assn., 1929).

11. California Library Association, Certification Committee, "Professional versus Non-Professional Positions in Libraries," Handbook and Proceedings of the Annual Meeting, 1932.

12. American Library Association, Office for Library Pérsonnel Resources, Library Education and Manpower (Chicago: American Library Assn., 1970).

13. American Library Association. Office for Library Personnel Resources, Library Education and Personnel Utilization (Chicago: American Library Assn., 1976).

14. Myrl R. Ricking and Robert E. Booth, Personnel Utilization in Libraries: A Systems Approach (Chicago: American Library Assn., 1974).

15. Charlotte Mugnier, The Paraprofessional and the Professional Job Structure (Chicago: American Library Assn., 1980).

16. Leslie-Beth Rothenberg and others, "A Job-Task Index for Evaluating Professional Utilization in Libraries," Library Quarterly 41:320-28 (Oct. 1971).

17. John. S. Evans, The Management of Human Capacity: An Approach to the Ideas of Elliott Jaques (London: MCB Pub., 1979), p. 82.

18. Richard B. Eggleton, "Achievement Motivation Theory as it Relates to Professional Personnel at College and University Libraries" (Ph.D. diss., Drexel Univ., 1978).

19. Edward E. Lawler, Pay and Organizational Effectiveness: A Psychological View (New York: McGrawHill, 1971).

20. Evans, Management of Human Capacity, p.93.

21. Lawler, Pay, p.5.

22. Elliott Jaques, Health Services: Their Nature and Organization, and the Role of Patients, Doctors, Nurses, and the Complementary Professions (London: Heinemann, 1978), p.114. 
23. Louis Kaplan, "Professionalism, Decision-Sharing, and Bureaucracy," in Studies in Library Management, Vol. 5, ed. Anthony Vaughan (London: Clive Bingley, 1979).

24. Ralph M. Edwards, "The Management of Libraries and the Professional Functions of Librarians," Library Quarterly 45:150-60 (Apr., 1975).

25. Elliott Jaques, A General Theory of Bureaucracy (London: Heinemann, 1976), p.99-111.

26. Ibid., p.99.

27. Gillian Stamp, "Levels and Types of Managerial Capability," Journal of Management Studies 18:279 (Mar., 1981).

28. Jaques, General Theory, p.102.

29. Lawler, Pay, p.212.

30. Paul S. Goodman, "An Empirical Examination of Elliott Jaques' Concept of Time-Span," Human Relations 20:155-70 (1967).

31. Elliott Jaques, "Essential Developments in Bureaucracy in the 1980's," Journal of Applied Behavioral Science 16:443 (1980).

32. Catherine G. Burke, "Defining Professionalism: Time-Span of Discretion and Levels of Work," (Los Angeles: School of Public Administration, Univ. of Southern California, 1984).

33. Stamp, "Levels and Types," p.279.

34. Jaques, General Theory, p.143.

35. Ibid., p.159.

36. Ralph Rowbottom and David Billis, "The Stratification of Work and Organizational Design," $\mathrm{Hu}$ man Relations 30:56 (1977).

37. Elliott Jaques, Free Enterprise, Fair Employment (New York: Crane Russak, 1982).

38. Stamp, "Levels and Types," p.287.

39. Jaques, General Theory, p.110.

40. Wilfred Brown and Elliott Jaques, Glacier Project Papers (London: Heinemann, 1965).

41. Roy Richardson, Fair Pay and Work (Carbondale, Ill.: Southern Illinois Univ. Pr., 1971).

42. G. E. Krimpas, in E. Jaques, General Theory, p.229.

43. Donald P. Gould, "An Examination of Levels of Work in Academic Library Technical Services Departments Utilizing Time-Stratified Systems Theory," (Ph.D. diss., Univ. of Southern California, 1984).

44. Elliott Jaques, Equitable Payment: A General Theory of Work, Differential Payment and Individual Progress, 2 d ed. (Carbondale, Ill.: Southern Illinois Univ. Pr., 1970), p.156-58.

45. Evans, Management of Human Capacity, p.167.

46. John Lofland and Lyn $\mathrm{H}$. Lofland, Analyzing Social Settings: A Guide to Qualitative Observation and Analysis, 2d ed. (Belmont, Calif.: Wadsworth, 1984), p.12.

47. Elliott Jaques, Time-Span Handbook (London: Heinemann, 1964).

48. Evans, Management of Human Capacity, p.82.

49. Jaques, Free Enterprise, p.89.

50. American Library Association, Library Education, p.2.

51. Gould, "Examination of Levels of Work," p.158-62.

52. Jaques, Free Enterprise, p.156-58.

53. Evans, Management of Human Capacity, p.160. 